Abstracta Iranica Iranica

Revue bibliographique pour le domaine irano-aryen

Volume 32-33 | 2013

Comptes rendus des publications de 2009-2010

\title{
Yukako Goto. Safavid Capitals and their Coronation Ceremonies
}

Akihiko Yamaguchi

\section{OpenEdition}

1 Journals

\section{Electronic version}

URL: http://journals.openedition.org/abstractairanica/40661

DOI: 10.4000/abstractairanica.40661

ISSN: 1961-960X

Publisher:

CNRS (UMR 7528 Mondes iraniens et indiens), Éditions de l'IFRI

\section{Printed version}

Date of publication: 1 December 2013

ISSN: 0240-8910

\section{Electronic reference}

Akihiko Yamaguchi, "Yukako Goto. Safavid Capitals and their Coronation Ceremonies », Abstracta Iranica [Online], Volume 32-33 | 2013, document 239, Online since 01 July 2016, connection on 03 October 2020. URL : http://journals.openedition.org/abstractairanica/40661 ; DOI : https://doi.org/ 10.4000/abstractairanica.40661

This text was automatically generated on 3 October 2020.

Tous droits réservés 


\title{
Yukako Goto. Safavid Capitals and their Coronation Ceremonies
}

\author{
Akihiko Yamaguchi
}

\section{REFERENCES}

Yukako Goto. « Safavid Capitals and their Coronation Ceremonies ». The Kwansei Gakuin Historical Review, 37, 2010, p. 19-48 [in Japanese].

1 This article recounts the history of the Safavid coronation ceremony while identifying three of its basic - Islamic, mystic, and secular - elements. The Safavid enthronement ceremony was originally designed to demonstrate the new ruler's rightful inheritance of Safavid leadership and his legitimacy as ruler of a Shiite state. However the third ruler, Šāh Esmā'îl II, crowned at the end of a civil war of succession, attached more importance to the ceremony's secular aspects. Wearing the three objects symbolizing the imperial throne - crown, sword and belt - he held a grand coronation ceremony to publicly display his royal authority. Since his successors followed this pattern, the ceremony's mystical aspect gradually waned.

\section{AUTHORS}

\section{AKIHIKO YAMAGUCHI}

University of the Sacred Heart, Tokyo 